\title{
Pengujian Sistem Konversi Energi Suara menjadi Energi Listrik menggunakan Piezoelektrik
}

\author{
Eddy Wijanto', Budi Harsono ${ }^{2}$, Rendy Renandy ${ }^{3}$, Ade Septian', Kevin Sutanto ${ }^{5}$ \\ Program Studi Teknik Elektro, Fakultas Teknik dan Ilmu Komputer \\ Universitas Kristen Krida Wacana - Jakarta \\ 1eddy.wiyanto@ukrida.ac.id, budi.harsono@ukrida.ac.id, \\ ${ }^{3}$ rendy.2015te002@civitas.ukrida.ac.id, ${ }^{4}$ ade.2015te007@civitas.ukrida.ac.id, \\ ${ }^{5}$ kevin.2015te008@civitas.ukrida.ac.id
}

\begin{abstract}
Ringkasan
Beberapa penelitian terkait energi terbarukan, seperti energi air, angin, dan bahkan nuklir telah dilakukan. Namun, suara sebagai energi mekanik, ternyata juga memiliki potensi untuk menjadi salah satu alternatif energi. Sebagai konsekuensi dari Hukum Kekekalan Energi, energi suara dapat diubah menjadi energi listrik. Dalam penelitian ini dilakukan pengujian sistem konversi energi suara menjadi energi listrik, dengan memanfaatkan komponen piezoelektrik. Berdasarkan data baseline dari beberapa area jalan dan pabrik, dilakukan pengukuran dengan menggunakan signal generator sebagai sumber suara dan piezoelectric sebagai transducer yang mengkonversi energi suara menjadi energi listrik. Nilai frekuensi yang dihasilkan berada pada kisaran tertentu, dan nilai tertinggi berkisar diantara 760-780 Hz. Semakin dekat sumber suara, resonansi semakin sering terjadi dan tegangan yang dihasilkan Piezoelectric Transducer semakin besar.
\end{abstract}

Kata kunci: energi terbarukan, energi suara, konversi energi, piezoelektrik

\section{Pendahuluan}

Berdasarkan data dari Statistical Review of World Energy, Indonesia dengan jumlah penduduk terbesar keempat di dunia setelah Cina, India, dan Amerika Serikat, berada pada posisi ke 20 pada tingkat konsumsi energi dunia dengan total konsumsi sebesar $1,1 \%$ dari total energi dunia. Data yang dikeluarkan oleh kementerian ESDM dalam Blue Print Pengelolaan Energi Nasional menunjukkan bahwa dengan kondisi produksi minyak saat ini dan perjanjian bagi hasil yang sedang berlaku, Indonesia harus mengimpor minyak mentah sebesar 487 ribu barel per hari dan produk minyak sebesar 212 ribu barel per hari, melebihi besar ekspor minyak mentahnya sebesar 514 ribu barel per hari [1].

Kebutuhan akan energi di Indonesia makin berkembang seiring dengan pesatnya peningkatan pembangunan di bidang teknologi, industri, dan informasi. Dengan tingginya konsumsi energi di Indonesia dan semakin berkurangnya cadangan energi fosil, maka Indonesia sudah saatnya untuk secara serius mengembangkan energi non fosil, diantaranya dengan energi terbarukan. Berbagai bentuk energi terbaru telah dikembangkan, diantaranya tenaga angin, tenaga uap, biomassa, dan sebagainya [1]. 
Tabel 1. Ketersediaan Energi

\begin{tabular}{|c|c|c|}
\hline No. & Jenis Energi & Ketersediaan Energi (MW) \\
\hline 1. & Batubara & 28.050 \\
\hline 2. & Gas & 14.760 \\
\hline 3. & Minyak & 320 \\
\hline 4. & Solar & 4.060 \\
\hline 5. & Panas Bumi & 430 \\
\hline 6. & Air & 10.310 \\
\hline 7. & Biomass & 460 \\
\hline 8. & Lain-lain & 370 \\
\hline
\end{tabular}

Hukum Kekekalan Energi menyatakan bahwa energi tidak dapat diciptakan maupun dimusnahkan, energi hanya dapat berubah bentuk. Dengan hukum tersebut, pada dasarnya energi suara juga dapat diubah bentuknya menjadi energi listrik yang dapat dimanfaatkan untuk berbagai kebutuhan manusia. Lokasi-lokasi dengan tingkat kebisingan yang tinggi, seperti di jalan raya, dimana arus lalu lintas cukup padat di Indonesia, khususnya di kota-kota besar; di pabrik, juga memiliki tingkat kebisingan yang tinggi. Melihat adanya peluang tersebut, penelitian ini dilakukan untuk menghasilkan sebuah sistem konversi energi suara kebisingan menjadi energi listrik [1].

\section{Konsep Dasar}

\subsection{Energi Terbarukan}

Konsep energi terbarukan mulai dikenal pada tahun 1970. Ide pengembangan energi terbarukan muncul seiring dengan semakin terbatasnya energi fosil yang merupakan energi tak terbarukan. Pada dasarnya, energi terbarukan merupakan sumber energi yang dapat dengan cepat dipulihkan kembali secara alami dan prosesnya berkelanjutan. Energi terbarukan senantiasa tersedia di alam dalam waktu yang relatif sangat panjang [1].

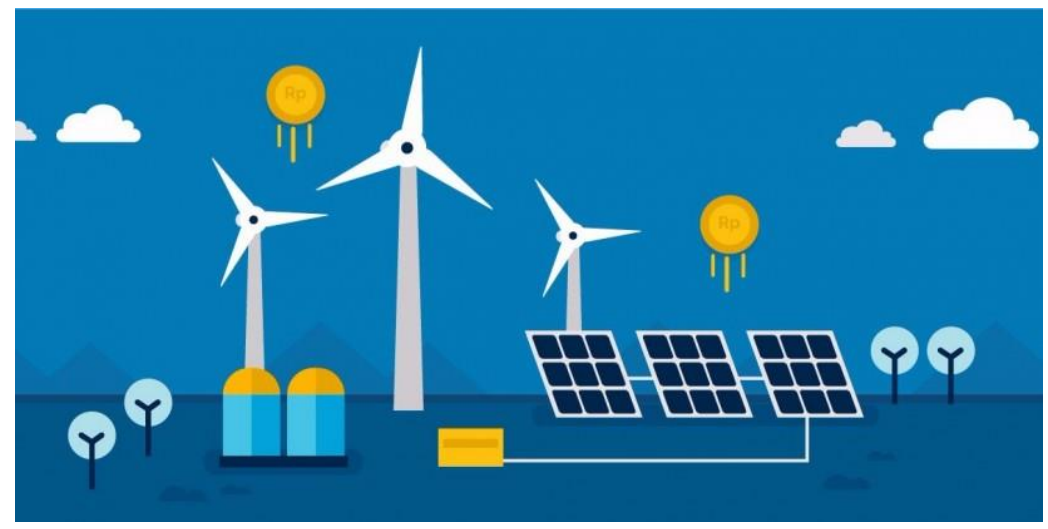

Gambar 1. Energi Terbarukan [1]

Energi terbarukan bersifat ramah lingkungan, aman, dan terjangkau masyarakat. Penggunaan energi terbarukan lebih ramah lingkungan karena mampu mengurangi pencemaran lingkungan dan kerusakan lingkungan dibandingkan dengan energi tak terbarukan. Adapun contoh dari energi terbarukan adalah sebagai berikut:

1. Angin

Angin merupakan salah satu sumber energi yang terbarukan. Selama bumi ini masih ada, maka angin akan tetap ada selamanya karena ketersediaannya tidak 
terbatas. Angin seringkali dimanfaatkan dalam teknologi kincir angin, khususnya di negara dengan intensitas angin yang tinggi. Angin ini akan mendorong turbin dari kincir angin yang dapat menghasilkan energi listrik.

2. Matahari

Matahari merupakan sumber energi paling penting dalam kehidupan manusia. Sumber energi panas dari matahari juga banyak digunakan untuk berbagai macam aktivitas, seperti fotosintesis buatan, listrik tenaga surya, dan sebagainya.

3. Panas Bumi

Sumber energi panas bumi atau geothermal merupakan energi panas dari kerak bumi. Energi geothermal diperoleh akibat peluruhan radioaktif dan juga pelepasan kalor atau panas secara terus-menerus di dalam bumi.

4. Biofuel

Biofuel merupakan bahan bakar yang dihasilkan dari bahan-bahan organik. Sumber dari energi terbarukan ini adalah tanaman yang memiliki kandungan gula tinggi, seperti tebu dan sorgum, serta tanaman yang memiliki kandungan minyak nabati tinggi, seperti kelapa sawit, ganggang, dan jarak.

5. Air

Energi air juga merupakan energi alternatif yang dapat digunakan sebagai pengganti bahan bakar fosil. Sumber energi ini didapatkan dengan memanfaatkan energi potensial dan energi kinetik yang dimiliki oleh air.

6. Biomassa

Biomassa merupakan energi terbarukan yang mengacu pada bahan biologis yang berasal dari organisme yang masih hidup ataupun yang belum lama mati.

\subsection{Suara dan Energi Suara}

Suara atau kebisingan merupakan salah satu sumber energi yang tersedia secara luas. Suara pada dasarnya merupakan gelombang mekanik yang dihasilkan dari osilasi tekanan melalui beberapa media. Suara yang dapat didengar oleh indera pendengaran manusia memiliki frekuensi dari sekitar $20 \mathrm{~Hz}$ sampai $20.000 \mathrm{~Hz}$. Di udara pada suhu dan tekanan standar, panjang gelombang suara berkisar dari $17 \mathrm{~m}$ sampai $17 \mathrm{~mm}$.

Energi suara adalah energi yang dihasilkan oleh getaran suara saat melakukan perjalanan melalui udara, air, atau ruang lainnya. Frekuensi dari sumber energi suara yang pertama adalah infrasonik. Infrasonik adalah suara yang sangat lemah karena jumlah getaran yang dihasilkan pada gelombang infrasonik kurang dari 20 getaran per detik. Audiosonik adalah jenis suara yang dapat didengar oleh manusia. Gelombang Ultrasonik adalah gelombang dengan jumlah getaran suara lebih dari 20.000 getaran per detik.

Kebisingan adalah polusi suara yang pada umumnya terjadi pada daerah-daerah pemukiman yang padat, kawasan industri, dan lain-lain. Oleh karena itu, kebisingan yang merupakan energi suara yang terbuang, biasanya diminimalisasi. Efek psikologis dan kesehatan yang ditimbulkan oleh kebisingan, antara lain tuli, merasa tertekan, hipertensi, dan lain-lain. Untuk mencegah hal-hal tersebut, pekerja yang berada di daerah dengan tingkat kebisingan tinggi pada umumnya diwajibkan memakai pelindung [2].

Sebagai salah satu bentuk energi, kebisingan dapat dimanfaatkan. Hambatan dalam penggunaan energi kebisingan ini, antara lain kekonsistenan dari sumber energi 
kebisingan. Untuk kawasan industri yang mengoperasikan mesin-mesin secara terusmenerus, kebisingan relatif konstan. Solusi untuk permasalahan ini antara lain dengan mengefektifkan komponen penyimpanan energi.

Salah satu pemanfaatan energi kebisingan adalah pada Sound-Driven Piezoelectric Nanowire. Penelitian ini dilakukan oleh beberapa peneliti asal Korea Selatan dimana dalam penelitian ini sumber energi telepon akan diperoleh dari energi suara pembicaraan dan suara lain yang ada di sekitarnya, seperti suara kebisingan yang dihasilkan oleh kendaraan yang melintas [3]. Adapun kelemahan dari penelitian ini adalah tingkat energi yang dihasilkan masih cukup kecil dan belum ada mekanisme optimalisasi dan penyimpanan energi.

Penelitian lain mengenai pemanfaatan energi suara dilakukan oleh Orest Symko yang memanfaatkan energi suara yang berasal dari udara untuk mengubahnya menjadi energi listrik. Prosesnya dilakukan dengan sebuah silinder yang ditempatkan di antara hot heat exchanger dan cold heat exchanger. Selanjutnya panas diberikan sehingga udara akan mengalir dan akan mengeluarkan suara dengan frekeunsi tertentu. Adanya frekeunsi ini akan mengakibatkan terjadinya fenomena resonansi. Frekuensi ini akan mengakibatkan silinder bergerak dan menekan piezoelektrik sehingga menghasilkan energi listrik. Penelitian ini lebih berfokus kepada perancangan sensor suara.

Berdasarkan dua penelitian sebelumnya, pada penelitian ini akan dirancang sebuah sistem konversi energi suara menjadi energi listrik, sebagai konsekuensi dari Hukum Kekekalan Energi, dimana suara sebagai energi mekanik dapat diubah menjadi energi listrik [4]. Penelitian ini diawali dengan pengambilan data baseline di beberapa lokasi dengan tingkat kebisingan suara yang cukup tinggi, seperti pabrik dan jalan raya. Berdasarkan hasil data awal tersebut, signal generator digunakan sebagai pengganti sumber suara. Suara yang dihasilkan dari signal generator kemudian difokuskan dengaan memanfaatkan tabung resonansi untuk selanjutnya dikonversi menjadi energi listrik dengan piezoelektrik.

\subsection{Piezoelektrisitas}

Piezoelektrisitas adalah sebuah fenomena saat sebuah gaya yang diterapkan pada suatu bahan menimbulkan muatan listrik pada permukaan bahan tersebut yang disebabkan oleh adanya distribusi muatan listrik pada sel-sel kristal. Nilai koefisien muatan piezoelektrik berada pada rentang 1-100 pico coloumb/Newton.

Piezoelectric berasal dari bahasa Yunani, yaitu piezo yang berarti tekanan dan electric yang berarti listrik. Material Piezoelectric pertama kali ditemukan pada tahun 1880 oleh Jacques dan Pierre Curie. Jacques dan Pierre Curie mengombinasikan pengetahuan akan piroelektrisitas (kemampuan bahan-bahan tertentu untuk menghasilkan sebuah potensial listrik saat bahan-bahan itu dipanaskan atau didinginkan) dengan pemahaman akan struktur dan perilaku sebuah kristal pada kristal turmalin, kuarsa, dan garam rossel. Dari uji coba tersebut diketahui bahwa kristal kuarsa dan garam rossel memperlihatkan kemampuan piezoelektrisitas paling besar saat itu [5]. Bahan piezoelektrik adalah suatu bahan yang apabila diberikan tekanan mekanik akan menghasilkan medan listrik, sebaliknya apabila medan listrik diterapkan pada bahan piezoelectric akan terjadi deformasi mekanik. Sifat yang reversible ini membuat material Piezoelectric dapat berfungsi sebagai transduser dan aktuator [6].

Adapun kelebihan dari piezoelectric adalah piezoelectric tidak memerlukan daya dari luar dan dapat digunakan pada perangkat yang berukuran kecil, sedangkan kelemahan 
dari piezoelectric adalah adanya kebocoran muatan pada material piezoelectric, sehingga ada suatu konstanta waktu penyimpanan tegangan setelah diberikan gaya [7].

\section{Hasil dan Pembahasan}

\subsection{Data Baseline}

Untuk merancang sistem konversi energi suara kebisingan menjadi energi listrik, dilakukan pengambilan data baseline di beberapa area jalan dan pabrik. Adapun hasil yang diperoleh adalah sebagai berikut:

1. Ruas Jalan: Kawasan Perumahan Banjar Wijaya Tangerang

Hasil yang diperoleh:

a. Rata-Rata Kebisingan Suara sekitar $87 \mathrm{~dB}$

b. Frekuensi berkisar antara $50-500 \mathrm{~Hz}$

c. Lokasi jalan jarang dilalui kendaraan bermotor.

Jalan Daan Mogot

Hasil yang diperoleh:

a. Rata-Rata Kebisingan Suara sekitar $90 \mathrm{~dB}$

b. Frekuensi berkisar antara $50-100 \mathrm{~Hz}$

c. Lokasi jalan cukup banyak dilalui kendaraan bermotor sebagai jalan utama

2. Pabrik: PT Karilla Berkat Abadi, Berlokasi di Jl. Quary D. No. 38 RT. 05 RW. 01 Kp. Lulut, Desa Lulut, Kec. Klapanunggal, Kab. Bogor. Konsentrasi Produk: Katup Tabung LPG dan Katup Tabung Baja LPG

Kesimpulan dari hasil pengambilan data di PT Karilla Berkat Abadi:

a. Rata-rata kebisingan suara sekitar $100 \mathrm{~dB}$

b. Frekuensi berkisar antara $5-10 \mathrm{kHz}$

PT Indodaya Cipta Lestari; Lokasi: Jl. Nusa Indah No. 62/63, Kapuk, Cengkareng, Kota Jakarta Barat, DKI Jakarta. Konsentrasi Produk: Trafo (Transformator) dan Power Supply

\subsection{Hasil Pengamatan}

Berdasarkan data baseline yang telah diperoleh, dilakukan pengukuran dengan menggunakan signal generator sebagai sumber suara, tabung resonansi untuk memfokuskan suara yang akan dikonversi, piezoelektrik sebagai transducer pengubah energi getaran suara menjadi energi listrik. Adapun pengukuran dilakukan dengan beberapa kondisi yang berbeda.

1. Kondisi I: Sumber suara sejauh $2,5 \mathrm{~cm}$ dari ujung tabung yang diamati, Panjang tabung 0,99 $\mathrm{m}$ dengan diameter $5,5 \mathrm{~cm}$

2. Kondisi II: Sumber suara sejauh $2 \mathrm{~cm}$ dari ujung tabung yang diamati, Panjang tabung 1,40 $\mathrm{m}$ dengan diameter $4 \mathrm{~cm}$

3. Kondisi III: Sumber suara sejauh $14 \mathrm{~cm}$ dari ujung tabung yang diamati, Panjang tabung 0,99 $\mathrm{m}$ dengan diameter $5,5 \mathrm{~cm}$

4. Kondisi IV: Sumber suara diletakkan $14 \mathrm{~cm}$ dari ujung tabung yang diamati, Panjang tabung adalah 1,40 $\mathrm{m}$ dan mempunyai diameter $4 \mathrm{~cm}$

Berdasarkan hasil pengukuran yang sudah dilakukan, dapat dirangkum dalam Gambar 7 - 10. Dari hasil pengukuran dapat dilihat bahwa nilai frekuensi yang dihasilkan akan berada pada kisaran tertentu, dan nilai tertinggi selalu berkisar diantara 
760-780 Hz. Semakin dekat sumber suara, resonansi semakin sering terjadi dan tegangan yang dihasilkan Piezoelectric Transducers semakin besar. Semakin panjang tabung yang digunakan, semakin rendah frekuensi yang dihasilkan

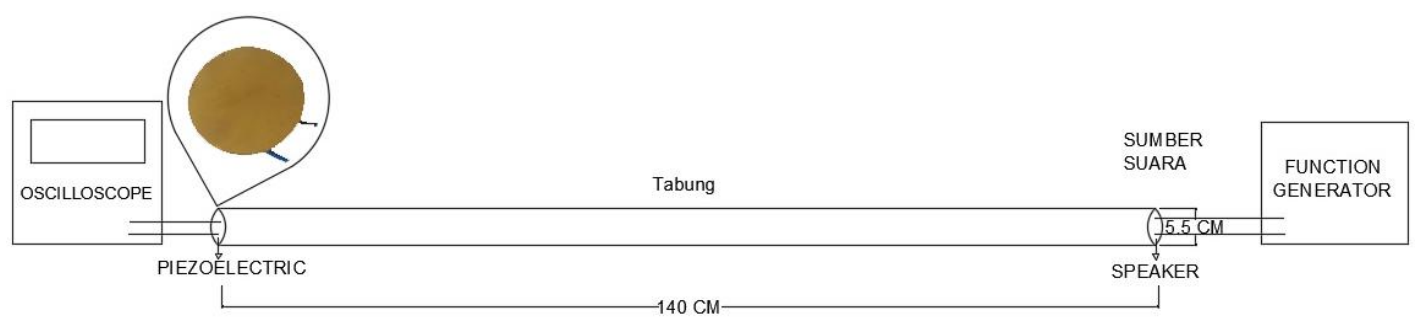

Gambar 2. Rancang bangun Piezoelectric

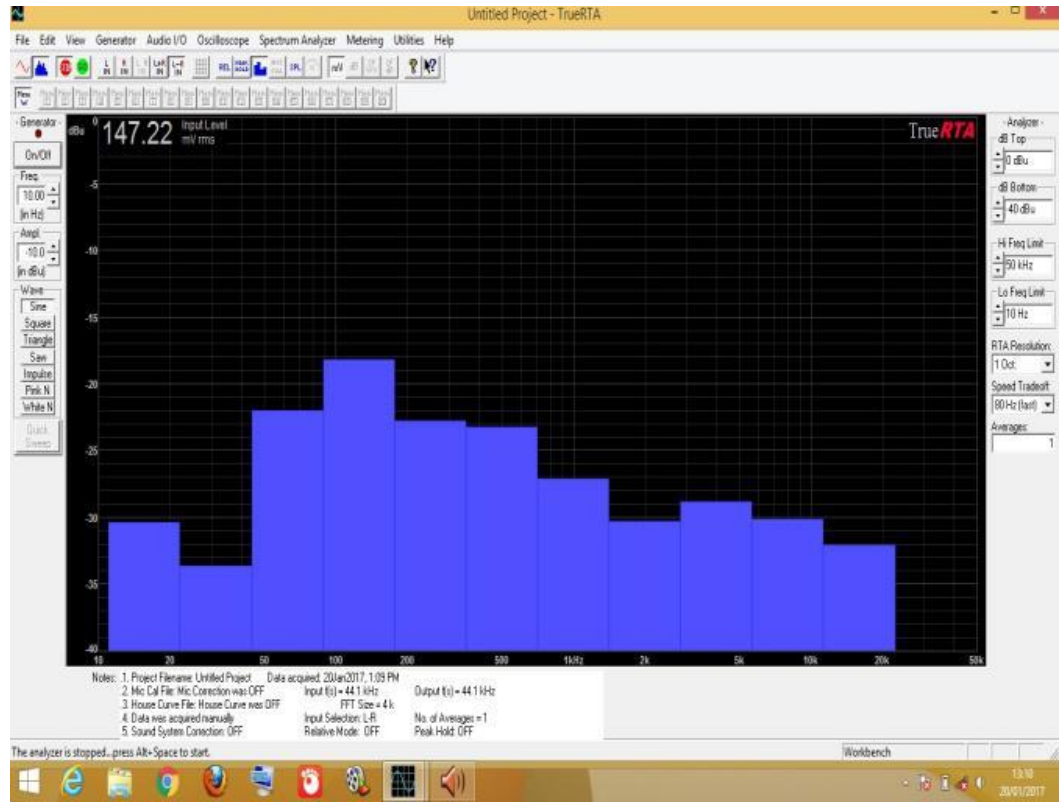

Gambar 3. Hasil pengukuran di Kawasan Perumahan Banjar Wijaya, Tangerang

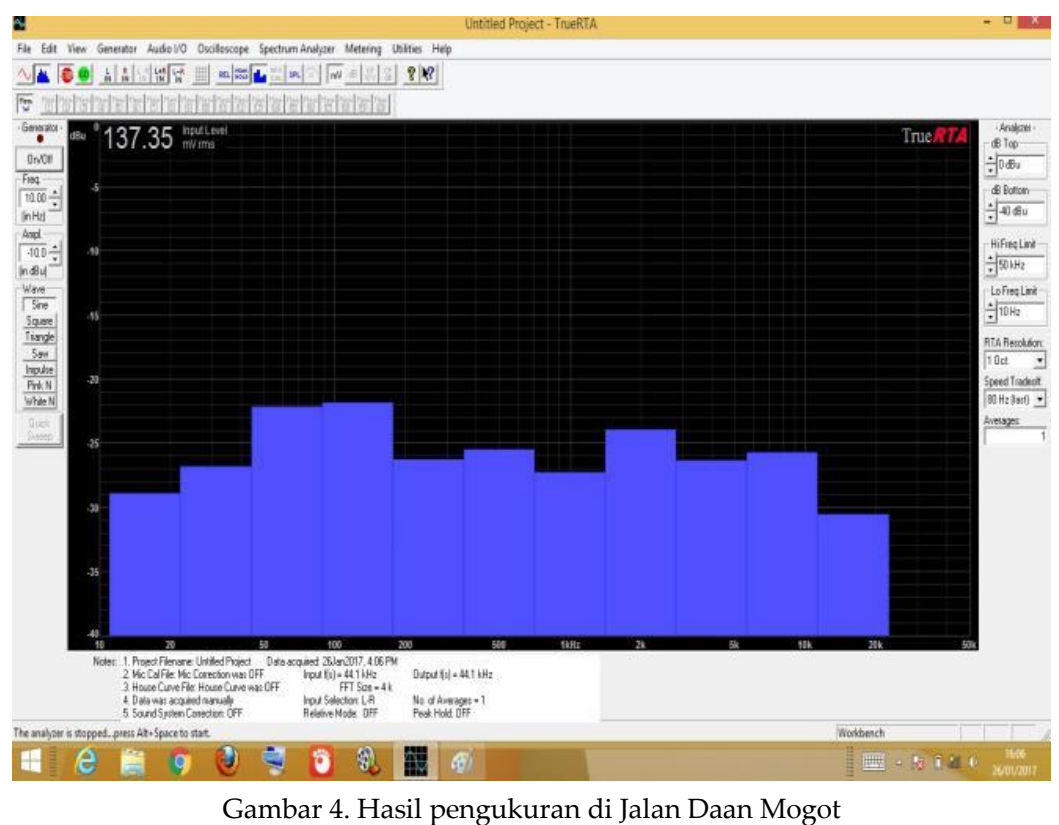


Pengujian Sistem Konversi Energi Suara menjadi Energi Listrik menggunakan

Piezoelektrik

Eddy Wijanto, Budi Harsono, Rendy Renandy, Ade Septian, Kevin Sutanto

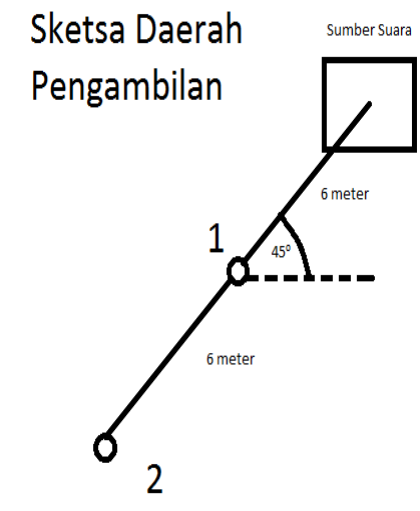

Gambar 5. Titik pengambilan data

Tabel 2. Hasil pengamatan di PT Karilla Berkat Abadi

\begin{tabular}{|c|c|c|}
\hline Pengamatan ke- & Hasil Posisi 1 & Hasil Posisi 2 \\
\hline Satu & $101,9 \mathrm{~dB}$ & $97,7 \mathrm{~dB}$ \\
\hline Dua & $101,9 \mathrm{~dB}$ & $98,1 \mathrm{~dB}$ \\
\hline Tiga & $101,5 \mathrm{~dB}$ & $102,3 \mathrm{~dB}$ \\
\hline Empat & $102,0 \mathrm{~dB}$ & $101,2 \mathrm{~dB}$ \\
\hline Lima & $102,2 \mathrm{~dB}$ & $101,1 \mathrm{~dB}$ \\
\hline
\end{tabular}

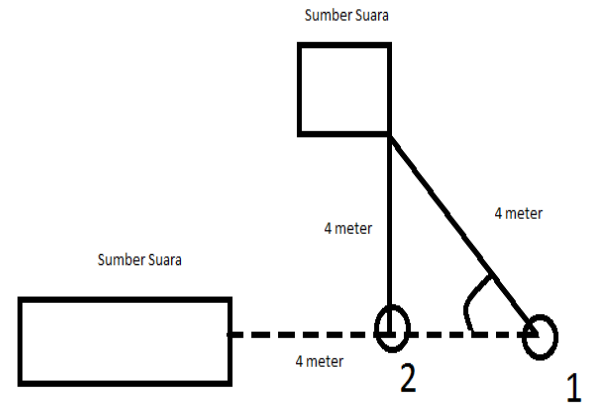

Gambar 6. Titik pengambilan data

Tabel 3. Hasil pengamatan di PT Indodaya Cipta Lestari

\begin{tabular}{|c|c|c|}
\hline Pengamatan ke- & Hasil Posisi 1 & Hasil Posisi 2 \\
\hline Satu & $97,9 \mathrm{~dB}$ & $99,7 \mathrm{~dB}$ \\
\hline Dua & $98,3 \mathrm{~dB}$ & $100,4 \mathrm{~dB}$ \\
\hline Tiga & $99,0 \mathrm{~dB}$ & $99,9 \mathrm{~dB}$ \\
\hline Empat & $98,6 \mathrm{~dB}$ & $100,1 \mathrm{~dB}$ \\
\hline Lima & $99,1 \mathrm{~dB}$ & $100,0 \mathrm{~dB}$ \\
\hline
\end{tabular}

Tabel 4. Hasil pengamatan untuk Kondisi I

\begin{tabular}{|c|c|c|c|c|c|c|c|c|c|c|}
\hline & \multicolumn{10}{|c|}{ Frekuensi } \\
\hline & 254,1 & 323,8 & 432,1 & 608,2 & 768,3 & 934,3 & 1,10 & 1,42 & 1,77 & 2,57 \\
\hline & $\mathrm{Hz}$ & $\mathrm{Hz}$ & $\mathrm{Hz}$ & $\mathrm{Hz}$ & $\mathrm{Hz}$ & $\mathrm{Hz}$ & $\mathrm{kHz}$ & $\mathrm{kHz}$ & $\mathrm{kHz}$ & $\mathrm{kHz}$ \\
\hline Vpeak & 14,2 & 16,8 & 32,8 & 22,4 & $272 \mathrm{mV}$ & 89,6 & 42,4 & 24,0 & 21,2 & 40,6 \\
\hline to peak & $\mathrm{mV}$ & $\mathrm{mV}$ & $\mathrm{mV}$ & $\mathrm{mV}$ & & $\mathrm{mV}$ & $\mathrm{mV}$ & $\mathrm{mV}$ & $\mathrm{mV}$ & $\mathrm{mV}$ \\
\hline
\end{tabular}

Tabel 5. Hasil pengamatan untuk Kondisi II

\begin{tabular}{|c|c|c|c|c|c|c|c|c|c|c|}
\hline & \multicolumn{10}{|c|}{ Frekuensi } \\
\cline { 2 - 10 } & $\begin{array}{c}227,3 \\
\mathrm{~Hz}\end{array}$ & $\begin{array}{c}426,4 \\
\mathrm{~Hz}\end{array}$ & $\begin{array}{c}561,6 \\
\mathrm{~Hz}\end{array}$ & $\begin{array}{c}783,1 \\
\mathrm{~Hz}\end{array}$ & $\begin{array}{c}906,3 \\
\mathrm{~Hz}\end{array}$ & $\begin{array}{c}1,02 \\
\mathrm{kHz}\end{array}$ & $\begin{array}{c}1,14 \\
\mathrm{kHz}\end{array}$ & $\begin{array}{c}1,56 \\
\mathrm{kHz}\end{array}$ & $\begin{array}{c}2,42 \\
\mathrm{kHz}\end{array}$ & $\begin{array}{c}2,65 \\
\mathrm{kHz}\end{array}$ \\
\hline Vpeak & 12,8 & 29,2 & 36,4 & 230,4 & 62,4 & 24,0 & 17,6 & 12,0 & 17,2 & 38,4 \\
to peak & $\mathrm{mV}$ & $\mathrm{mV}$ & $\mathrm{mV}$ & $\mathrm{mV}$ & $\mathrm{mV}$ & $\mathrm{mV}$ & $\mathrm{mV}$ & $\mathrm{mV}$ & $\mathrm{mV}$ & $\mathrm{mV}$ \\
\hline
\end{tabular}


Techné Jurnal Ilmiah Elektroteknika Vol. 17 No. 1 April 2018 Hal 59 - 67

Tabel 6. Hasil pengamatan untuk Kondisi III

\begin{tabular}{|c|c|c|c|c|c|}
\hline & \multicolumn{5}{|c|}{ Frekuensi } \\
\cline { 2 - 6 } & $618,3 \mathrm{~Hz}$ & $785,8 \mathrm{~Hz}$ & $954,2 \mathrm{~Hz}$ & $1,12 \mathrm{kHz}$ & $1,41 \mathrm{kHz}$ \\
\hline $\begin{array}{c}\text { Vpeak to } \\
\text { peak }\end{array}$ & $9,0 \mathrm{mV}$ & $40 \mathrm{mV}$ & $18,4 \mathrm{mV}$ & $17,0 \mathrm{mV}$ & $8,8 \mathrm{mV}$ \\
\hline
\end{tabular}

Tabel 7. Hasil pengamatan untuk Kondisi IV

\begin{tabular}{|c|c|c|c|c|c|}
\hline & \multicolumn{5}{|c|}{ Frekuensi } \\
\cline { 2 - 6 } & $784,8 \mathrm{~Hz}$ & $950,3 \mathrm{~Hz}$ & $1,18 \mathrm{kHz}$ & $1,68 \mathrm{kHz}$ & $2,61 \mathrm{kHz}$ \\
\hline $\begin{array}{c}\text { Vpeak to } \\
\text { peak }\end{array}$ & $33,6 \mathrm{mV}$ & $11,6 \mathrm{mV}$ & $7,2 \mathrm{mV}$ & $11,4 \mathrm{mV}$ & $20,6 \mathrm{mV}$ \\
\hline
\end{tabular}

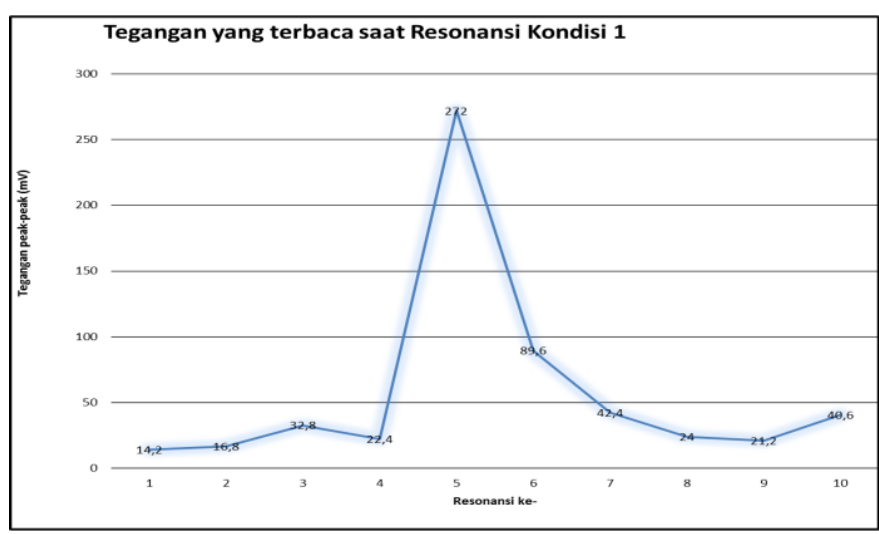

Gambar 7. Grafik hasil pengukuran Vpp untuk kondisi I

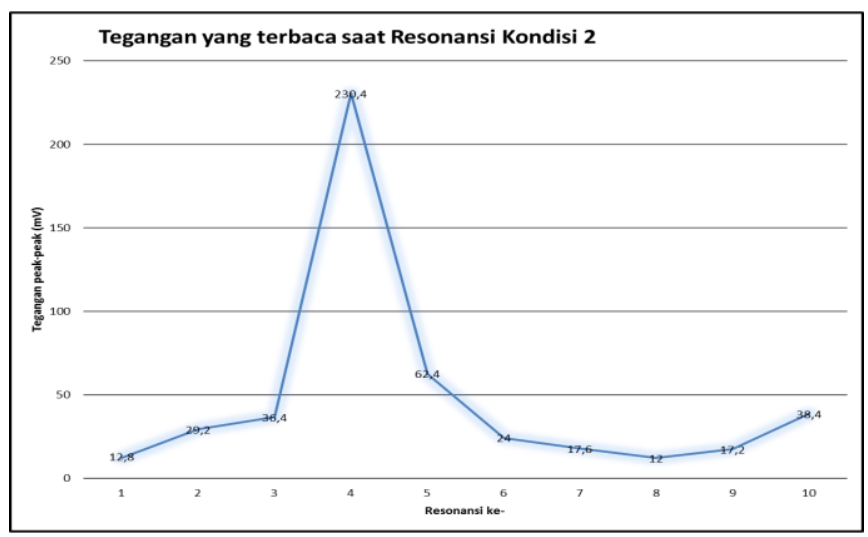

Gambar 8. Grafik hasil pengukuran Vpp untuk kondisi II

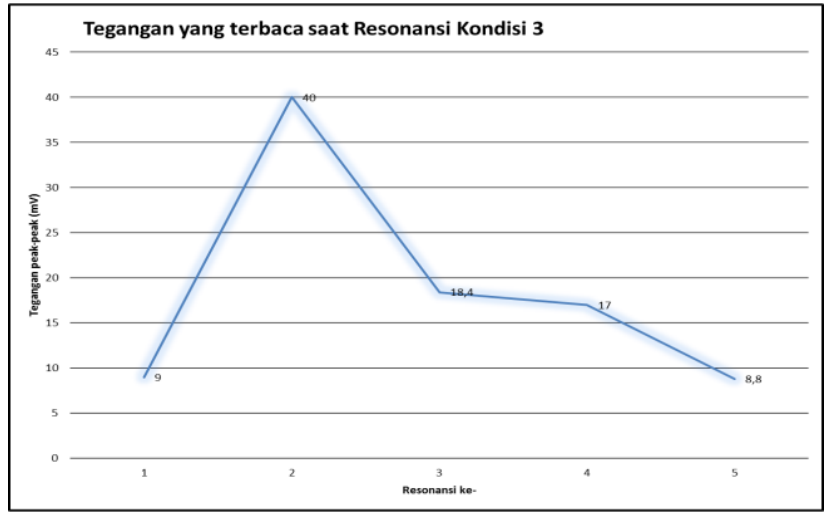

Gambar 9. Grafik hasil pengukuran Vpp untuk kondisi III 


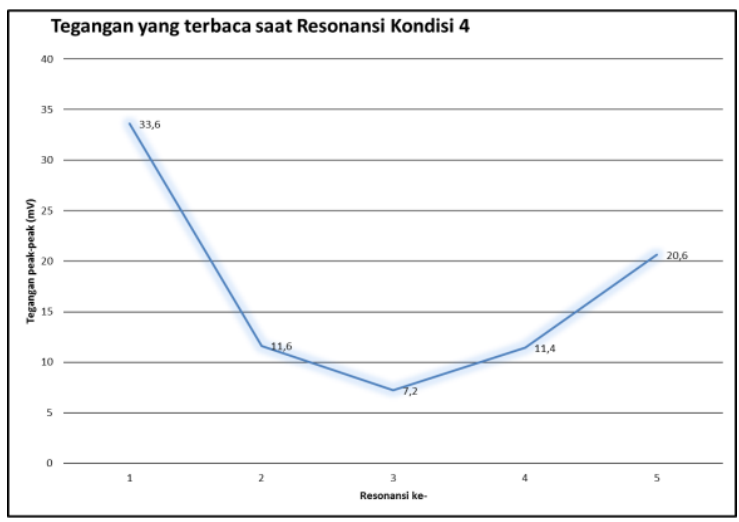

Gambar 10. Grafik hasil pengukuran Vpp untuk kondisi IV

\section{Kesimpulan}

Berdasarkan hasil pengukuran dan analisisnya, dapat disimpulkan sebagai berikut:

1. Dari hasil pengukuran data baseline, untuk area jalan raya, intensitas suara antara 87-90 dB sedangkan untuk area pabrik, intensitas suara 97-101 dB

2. Tegangan keluaran Piezoelectric Transducers akan semakin besar apabila sumber suara semakin dekat dengan ujung tabung.

3. Nilai frekuensi saat terjadi resonansi berkisar di antara $760-780 \mathrm{~Hz}$, dan berbanding terbalik dengan panjang tabung yang dipakai.

4. Energi suara memiliki potensi sebagai sumber energi alternatif yang terbarukan

5. Posisi alat terhadap sumber suara menentukan besaran energi listrik yang dihasilkan

\section{Daftar Pustaka}

[1]. Kementerian ESDM RI, "Peluang Menawan Bisnis Energi Terbarukan di Indonesia", Kompasiana, 2017.

[2]. Schaijk, Van, Elfrink, Kamel, Goedbloed, "Piezoelectric AIN Energy Harvesters for Wireless Autonomous Transducer Solutions", IEEE Sensors Conference, 2008.

[3]. Cha, Seung Nam, Ju-Seok Seo, Seong Min Kim, Hyun Jin Kim, Young Jun Park, Sang-Woo Kim, Jong Min Kim, "Sound-Driven Piezoelectric Nanowire-Based Nanogenerators", Advanced Materials, pp. 4726-4730, 2010.

[4]. Gupta, Alankrit, Vivek Goel, Vivek Yadav, "Conversion of Sound to Electric Energy", International Journal of Scientific and Engineering Research, Vol. 05 Issue 1, January 2014.

[5]. Saadon, Salem, Othman, "A Review of Vibration-Based MEMS Piezoelectric Energy Harvesters", Energy Conversion and Management, Vol. 52 Issue 1, pp. 500504, January 2011.

[6]. Kim, Heung Soo, Joo-Hyong Kim, Jaehwan Kim, "A Review of Piezoelectric Energy Harvesting Based on Vibration", International Journal of Precision Engineering and Manufacturing, Vol. 12 No. 8, pp. 1129-1141, 2011.

[7]. Minazara, Vasic, Costa, Poulin, "Piezoelectric Diaphragm for Vibration Energy Harvesting", Ultrasonics, Vol. 22, pp. e609-e703, December 2006. 
